\title{
Experimental Study on the Shock Absorption Performance of Combined Aluminium Honeycombs under Impact Loading
}

\author{
Lei Cao, ${ }^{1}$ Yuliang Lin, ${ }^{1}$ Fangyun Lu, ${ }^{1}$ Rong Chen, ${ }^{1}$ Zhifeng Zhang, ${ }^{2}$ and Yan $\mathrm{Li}^{2}$ \\ ${ }^{1}$ College of Science, National University of Defense Technology, Changsha 410073, China \\ ${ }^{2}$ Beijing Institute of Astronautic System Engineering, Beijing 100068, China \\ Correspondence should be addressed to Fangyun Lu; fylu@nudt.edu.cn
}

Received 27 January 2015; Revised 11 May 2015; Accepted 12 May 2015

Academic Editor: Sakdirat Kaewunruen

Copyright (c) 2015 Lei Cao et al. This is an open access article distributed under the Creative Commons Attribution License, which permits unrestricted use, distribution, and reproduction in any medium, provided the original work is properly cited.

\begin{abstract}
Shock absorption characteristics of combined aluminium honeycomb structures were studied experimentally. In the experiments, a testing platform was design to compare the shock absorption level of different honeycomb specimens quantitatively. The shock response curves of six test points mounted on the platform were recorded with acceleration sensors when the buffer was impacted by a bullet driven by high pressure gas. The maximum acceleration values in time domain and in specifically spectral domain were obtained based on spectral analysis. Comparing the data of combined aluminium honeycomb buffer and single aluminium honeycomb buffer, conclusion can be obtained that shock absorbing characteristic of combined aluminium honeycomb buffer is better. Furthermore, compression properties of three kinds of buffers were tested under quasi-static state. The energy absorption parameters were calculated. The results show suitable combined aluminium honeycomb buffer can smooth the stress and lower the energy applied to the testing platform.
\end{abstract}

\section{Introduction}

Aluminium honeycomb structures are widely used in various industrial applications because of their excellent physical and mechanical properties such as high strength/weight ratio, low mass/volume ratio, and high energy absorption capacity. For example, a wide variety of aluminium honeycombs are used as core materials of sandwich constructions, vibration dampers, shock absorbers, and so forth in astronautic, automobile, and shipbuilding industries [1-5].

In recent years, crushing properties and mechanics characteristics of the aluminium honeycomb have been investigated extensively, including in-plane dynamic response [68], out-of-plane crushing behaviour [9-23], and mechanical behaviour of sandwich panels with aluminium honeycombs [24-29]. Among all the investigations, the out-of-plane dynamic behaviour of bare aluminium honeycombs and that of sandwich panels with the cores of aluminium honeycombs are more often used in energy absorption design.

The quasi-static crushing behaviour of honeycombs under out-of-plane compressive loads has been investigated by many researchers [9-23]. Various experimental studies on quasi-static and dynamic crushing behaviours of honeycombs under out-of-plane compressive loads have been reported, and the results indicate that the crushing strengths under dynamic loading conditions in general are larger than the ones under quasi-static loading conditions [12-14]. Zhao and Gary used split Hopkinson viscoelastic pressure bar for dynamic test of aluminium honeycomb structure under outof-plane and in-plane loads. The results showed that out-ofplane crushing behaviour was affected by the loading rate and the mean crushing pressure was nearly the same for impact velocities from 2 to $28 \mathrm{~m} / \mathrm{s}$ [15]. Deshpande and Fleck and Hou et al. considered that micro-inertia was the reason for the increase of the out-of-plane crushing strength of aluminium honeycombs from Zhao's results $[16,17]$. On the other hand, Zhou and Mayer suggested that the air trapped in the honeycomb cells could be the main reason for the increased crush strength [13]. Hou et al. studied the mechanics behaviour of a series of aluminium honeycombs with different cell sizes under quasi-static and impact loadings, and performed a comprehensive numerical constitutive law 
TABLE 1: Chemical composition of aluminium alloy 3003 (wt \%).

\begin{tabular}{|c|c|c|c|c|c|c|c|}
\hline \multirow{2}{*}{$\mathrm{Mn}$} & \multirow{2}{*}{$\mathrm{Fe}$} & \multirow{2}{*}{$\mathrm{Si}$} & \multirow{2}{*}{$\mathrm{Cu}$} & \multirow{2}{*}{$\mathrm{Zn}$} & \multicolumn{2}{|c|}{ Others $^{(1)}$} & \multirow{2}{*}{$\mathrm{Al}$} \\
\hline & & & & & Each & Total & \\
\hline $1.0 \sim 1.5$ & $\begin{array}{l}0.70 \\
\max \end{array}$ & $\begin{array}{l}0.60 \\
\max \end{array}$ & $0.05 \sim 0.20$ & $\begin{array}{l}0.10 \\
\max \end{array}$ & 0.05 & 0.15 & Remainder \\
\hline
\end{tabular}

$\operatorname{Note}^{(1)}$ : other chemical compositions include $\mathrm{Mg}, \mathrm{Cr}, \mathrm{Ti}, \mathrm{V}, \mathrm{Pb}, \mathrm{Bi}, \mathrm{Ni}, \mathrm{B}$, and $\mathrm{Zr}$.

TABLE 2: Physical and mechanics properties of aluminium alloy 3003.

\begin{tabular}{lcccc}
\hline Density $\left(\mathrm{g} / \mathrm{cm}^{3}\right)$ & Young's modulus $(\mathrm{GPa})$ & Poisson's ratio & Tensile strength $(\mathrm{MPa})$ & Yield strength $(\mathrm{MPa})$ \\
\hline 2.73 & 69 & 0.33 & 200 & 185 \\
\hline
\end{tabular}

with rate insensitive to model the experimental results for different cell size/wall thickness/base material [17]. Khan et al. investigated in-plane and out-of-plane crushing properties of the aluminium honeycomb with digital image correlation (DIC). Results from DIC showed that the deformation nucleated from the shear band at $45^{\circ}$ in the sample [18]. Mohr and Doyoyo performed uniaxial compression experiments on aluminium honeycomb to investigate localization of deformation in cellular materials and proposed three mechanism of the nucleation and propagation of plastic collapse bands in aluminium honeycomb: (I) uncrushed material with deformation-induced imperfections; (II) crushed material containing folded cell walls; (III) an active interface between the uncrushed and crushed regions $[9,10]$. Xu et al. and Alavi Nia and Sadeghi studied the effect of strain rate on the behaviours of hexagonal honeycombs experimentally [19, 20]. Hong et al. investigated the quasi-static and dynamic crushing behaviour of aluminium 5052-H38 honeycombs under compression dominant combined loads and nonproportional compression dominant combined loads experimentally. Based on the experimental results, a macroscopic yield criterion as a function of the impact velocity was proposed [21-23].

Sandwich panel/beam structure with honeycomb core is identified as one of the potential protective structures. Many works have been carried out to study the dynamic response and energy absorption capacity of honeycomb sandwich beams and panels. Hazizan and Cantwell investigated the low velocity impact response of two aluminium honeycomb sandwich structures by conducting drop weight impact tests. A simple energy-balance model based on the dissipation of the incident energy of the projectile was constructed [24]. Lee et al. also investigated impact behaviour of aluminium honeycomb sandwich panels by a drop weight test setup. They developed dynamic nonlinear transient analysis which was carried out by a finite element simulation model based on continuum damage mechanics to account for nonlinear and elastoplastic behaviour [25]. Crupi et al. studied two types of aluminium honeycomb sandwiches under static and impact loading and investigated the failure mode and damage of the honeycomb panels with 3D computed tomography [26]. Ivañez and Sanchez-Saez investigated the response of sandwich beams with honeycomb core subjected to low velocity impact numerically. Good agreement, in terms of contact-force histories, energy histories, absorbed energy, and failure of the sandwich beam, was achieved between experimental data and numerical results [27].

In summary, lots of studies about aluminium honeycombs have been carried out. However, most of them focused on crushing properties and buffering properties of single honeycomb or sandwich panel/beam with single honeycomb core. There are relatively few studies which have been done to investigate the shock absorption properties of combined aluminium honeycomb. In this work, the shock absorption properties of two kinds of combined aluminium honeycomb buffers are studied experimentally. In order to quantitatively assess the shock absorption ability, a testing platform is design, on which combined aluminium honeycomb buffers and six groups of acceleration sensors are mounted. The vibration signals of six test points are recorded when the buffer is impacted by a bullet driven by high pressure gas. The spectral accelerations (within $4 \mathrm{kHz}$ and $8 \mathrm{kHz}$ ) are calculated using the spectral analysis method. In addition, compression properties of the two combined aluminium honeycomb samples and one single aluminium honeycomb sample are tested under quasi-static state. Based on the experimental results, the absorbed energy is calculated to discuss the reason of reducing vibration.

\section{Experimental Design}

The aluminium honeycomb used in the study is a commercial product. Base material of the honeycomb is aluminium alloy 3003 , which is one of Al-Mn series alloys. The chemical composition and mechanical properties of aluminium alloy 3003 is listed in Tables 1 and 2, respectively [30].

Two kinds of aluminium honeycombs with hexagonal cell are selected, as shown in Figure 1. One aluminium honeycomb is with single wall thickness $t=0.04 \mathrm{~mm}$ and side-length $d=1.8 \mathrm{~mm}$, which is called A honeycomb. The other is with $d=1.0 \mathrm{~mm}, t=0.03 \mathrm{~mm}$, which is called B honeycomb. In the experiments, the specimens of $\mathrm{A}$ and $\mathrm{B}$ honeycomb are machined with outside diameter of $29.5 \mathrm{~mm}$ and inside diameter of $9.5 \mathrm{~mm}$ by wire-cut electrical discharge machining (WEDM). The thickness dimensions of A honeycomb specimens are $8.0 \mathrm{~mm}, 10.0 \mathrm{~mm}$, and $12.5 \mathrm{~mm}$, respectively; the ones of $\mathrm{B}$ honeycomb specimens are $4.5 \mathrm{~mm}$ and $2.5 \mathrm{~mm}$. We assume that the aluminium honeycomb buffers are all with total thickness $12.5 \mathrm{~mm}$; two groups of combined honeycomb buffers $(8 \mathrm{~mm} \mathrm{~A}+4.5 \mathrm{~mm} \mathrm{~B}, 10 \mathrm{~mm}$ 


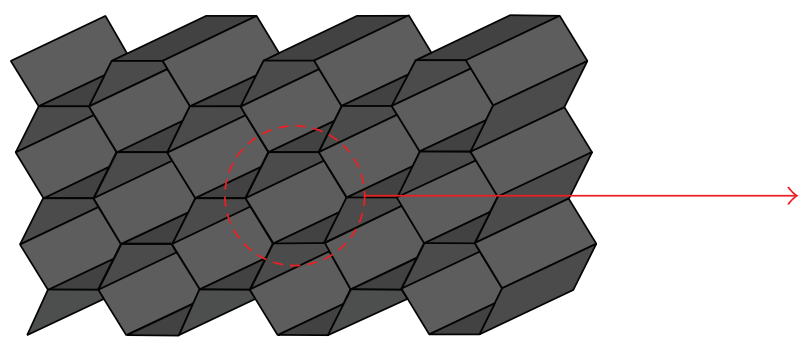

(a) Structural configuration

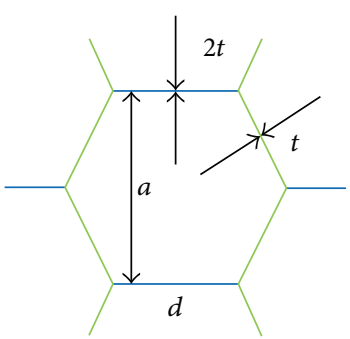

(b) Dimensions of a honeycomb cell

FIGURE 1: Aluminium honeycomb core geometry.

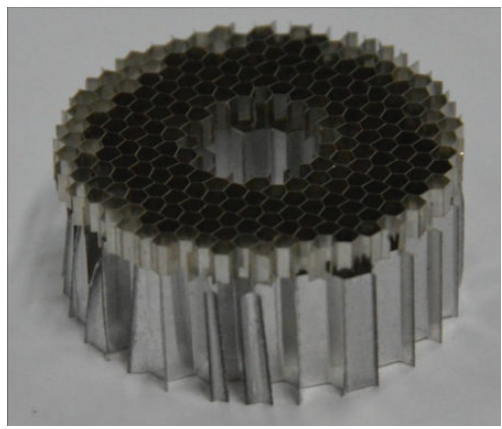

(a) $10 \mathrm{~mm} \mathrm{~A}+2.5 \mathrm{~mm} \mathrm{~B}$

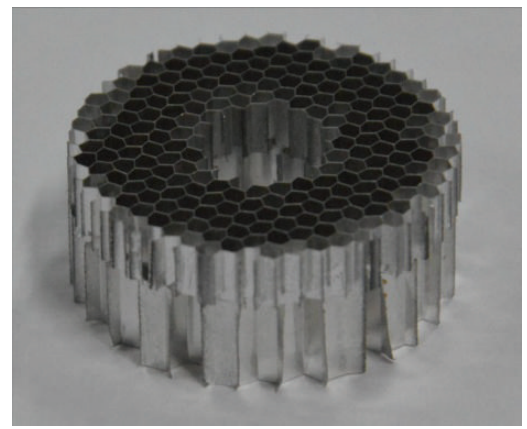

(b) $8 \mathrm{~mm} \mathrm{~A}+4.5 \mathrm{~mm}$

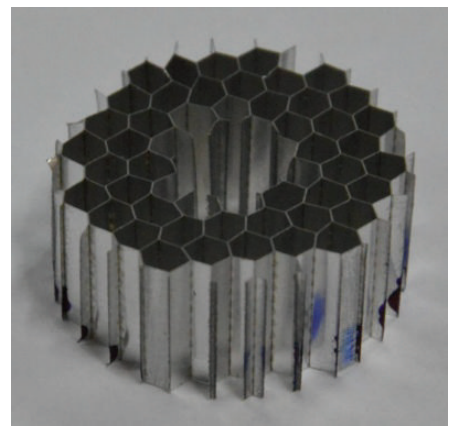

(c) $12.5 \mathrm{~mm} \mathrm{~A}$

Figure 2: Aluminium honeycombs specimens.

$\mathrm{A}+2.5 \mathrm{~mm} \mathrm{~B}$ ) and one single honeycomb buffer (12.5 mm A) are suitable. The specimens are shown in Figure 2.

A testing platform is designed to assess the shock absorption of aluminium honeycomb, as shown in Figure 3(a). The platform is made of 2024 aluminium alloy, whose dimensions are $600 \mathrm{~mm} \times 600 \mathrm{~mm} \times 20 \mathrm{~mm}$. In order to protect the main platform, an additional thin aluminium alloy sheet with dimensions of $\Phi 18 \mathrm{~mm} \times 2 \mathrm{~mm}$ is mounted on the centre of the platform. In the experiments, the aluminium honeycomb samples were pasted on the centre of the aluminium alloy sheet. The platform was hung by a pair of rubber belts fixed on two angles of the platform, which could insure that the platform moves freely when it was impacted by the bullet. In the tests, the platform was perpendicular to the ground, and axial direction of the specimen pasted on the centre of the platform was right consistent with impact direction of the bullet. A bullet with mass of $45.7 \mathrm{~g}$ is processed, whose diameter of raised section is $30.0 \mathrm{~mm}$, as shown in Figure 3(a). Six test points are selected to monitor the vibration response, whose location is indicated in Figure 3(b). Three acceleration sensors along $X, Y, Z$ directions are installed on each point.

The collection system of acceleration signals consists of acceleration sensors, charge amplifier, antialiasing filter, and digital oscillographs. The resonance frequency of acceleration sensor is $40 \mathrm{kHz}$; low pass filter of charge amplifier is set as $10 \mathrm{kHz}$; sample rate of oscillograph is set as $100 \mathrm{kS} / \mathrm{s}$.

A typical acceleration histories record is shown in Figure 4(a). Based on the data, the shock response spectrum (SRS) is calculated with the use of fast Fourier transform
(FFT), as shown in Figure 4(b). Then the acceleration maximum in time domain can be extracted from Figure 4(a); the acceleration maximum in spectral domain and corresponding frequency can be extracted from Figure 4(b). Since the shock response spectrum covers a wide range of frequencies, a certain frequency range is normally limited in practical use. In the study, the frequency range within $8 \mathrm{kHz}$ and $4 \mathrm{kHz}$ is concerned. In this work, the impact velocity of the bullet is controlled at around $30.0 \mathrm{~m} / \mathrm{s}$.

\section{Results and Discussion}

The impact experiments of three aluminium honeycomb buffers (as shown in Figure 2) were carried out with the impact velocity of around $30 \mathrm{~m} / \mathrm{s}$. According to the above steps (in Section 2), the shock response spectrum curves were calculated. Then the maximum accelerations (absolute) in time domain, and the one in spectral domain were extracted from the curves. The corresponding data of combined honeycomb buffer ( $8 \mathrm{~mm} \mathrm{~A}+4.5 \mathrm{~mm} \mathrm{~B})$ are listed in Table 3 .

As in Table 3, one can see that the acceleration maximums at each test point all appear on the $Z$ direction which is consistent with the direction of impact loading. In the study, maximums of the shock spectrum from all the testing points were considered as the representation of shock level in each test. 2 4 repeated experiments for each specimen were carried out in the tests. Comparing the maximum of the shock spectrums of repeated tests, the conclusion is obtained that the scatter of maximum acceleration is within $\pm 15 \%$, as 


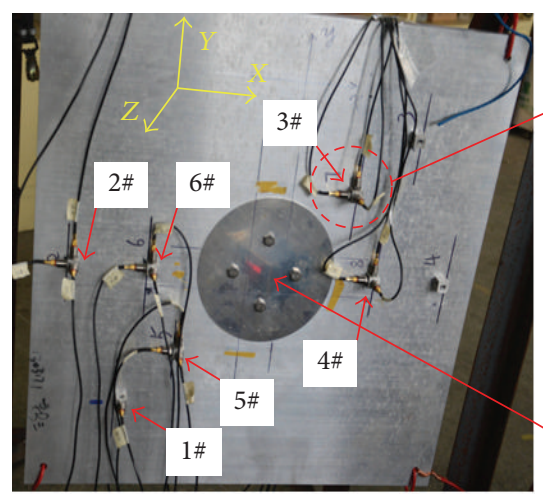

(a) Testing platform

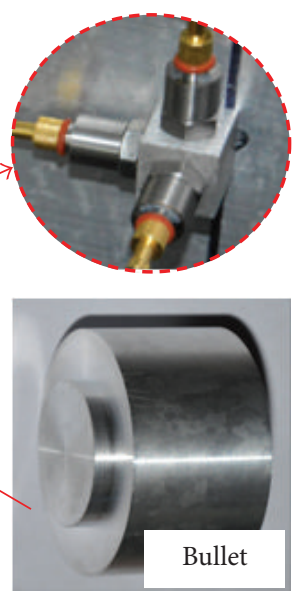

Figure 3: Experimental setup.

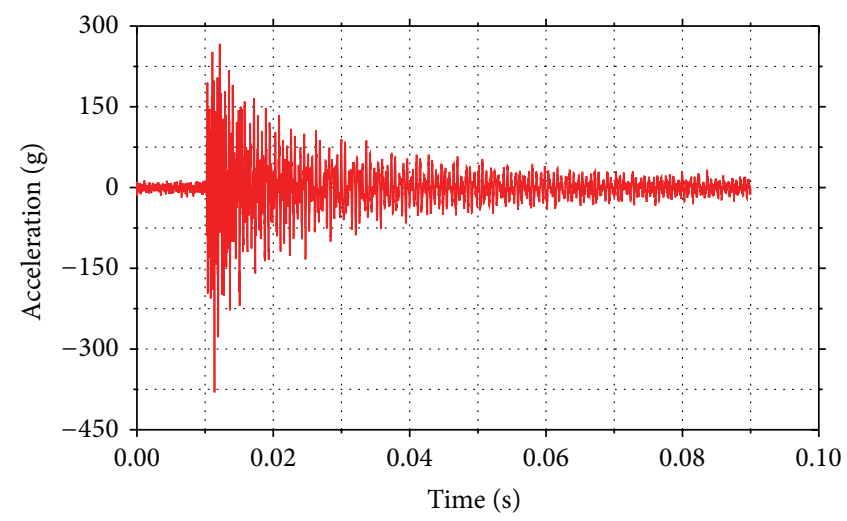

(a) Acceleration versus time

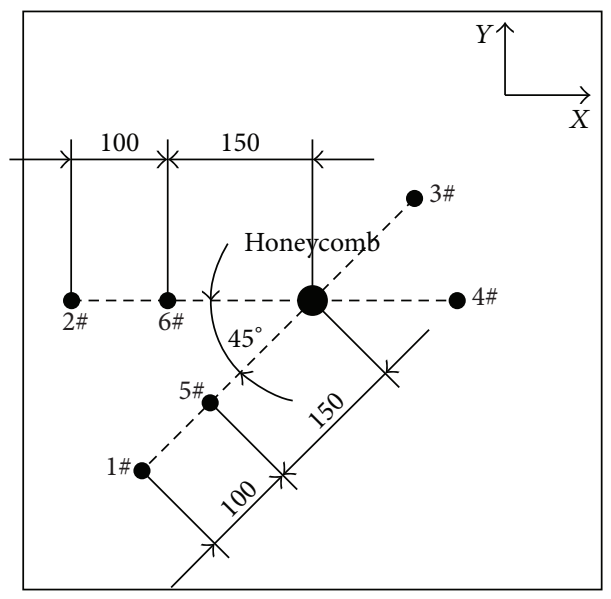

(b) Location of test points

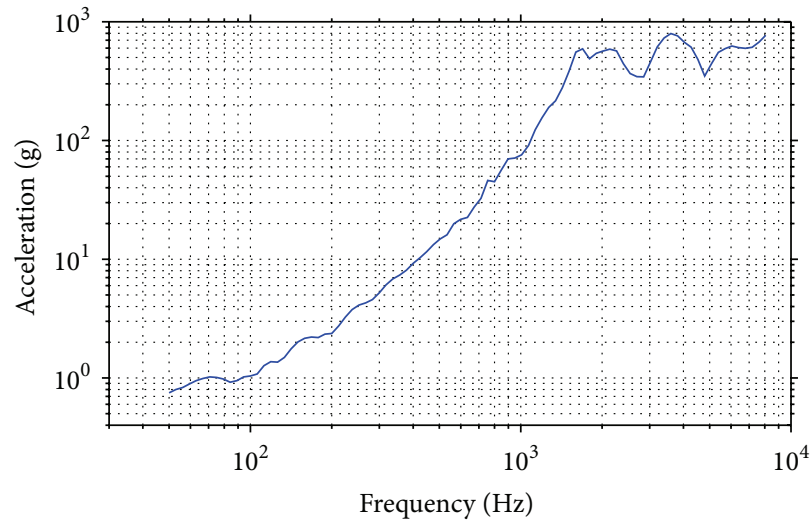

(b) Acceleration versus frequency

FIgURE 4: Typical experimental results.

in Table 4. As a result, all maximums of the shock spectrums for different buffers are shown in Figure 5. As in Figure 5, one can see that the maximum acceleration in each test point appears on the impact direction ( $Z$-direction), which is the one we focus on. Comparing the six groups of results along $Z$-direction, the conclusion can be obtained that black and red bars are all shorter than green bars. These show that the shock absorption of combined honeycomb buffer is better than that of single honeycomb buffer. The buffer of combined honeycomb $8 \mathrm{~mm} \mathrm{~A}+4.5 \mathrm{~mm} \mathrm{~B}$ is the most appropriate among them. The typical specimens after impact loading are presented in in Figure 6. The residual thickness of the specimen and the impact velocity of bullet in each experiment are listed in Table 5. As in Table 5, the residual thickness of $8 \mathrm{~mm} \mathrm{~A}+4.5 \mathrm{~mm}$ B buffer is biggest, which means the energy absorptivity is highest.

In order to investigate the energy absorption properties of the aluminium honeycomb, compression responses of three types of honeycombs were tested with the use of material test machine under quasi-static state (with displacement control of $2.0 \mathrm{~mm} / \mathrm{min}$ ). The typical results are shown in in Figure 7.
If the difference between dynamic compression properties and quasi-static compression properties is ignored, absorbed energy of the aluminium honeycomb buffers during the compression process can be analysed.

In the tests, total energy $\left(E_{\text {total }}\right)$ is kinetic energy of the bullet:

$$
E_{\text {total }}=\frac{1}{2} m v^{2},
$$

where $m$ is mass of the bullet and $v$ is impact velocity.

Absorbed energy $\left(E_{\text {absorbed }}\right)$ by the honeycomb specimens is calculated from the stress-displacement curves (as shown in in Figure 7),

$$
E_{\text {absorbed }}=S \int_{0}^{l_{0}-l_{\text {residual }}} \sigma d l \text {, }
$$

where $S$ is section area of the specimen which is considered as constant; $l_{0}$ and $l_{\text {residual }}$ are the initial and residual thickness of honeycomb specimens, respectively; $\sigma$ is stress. 


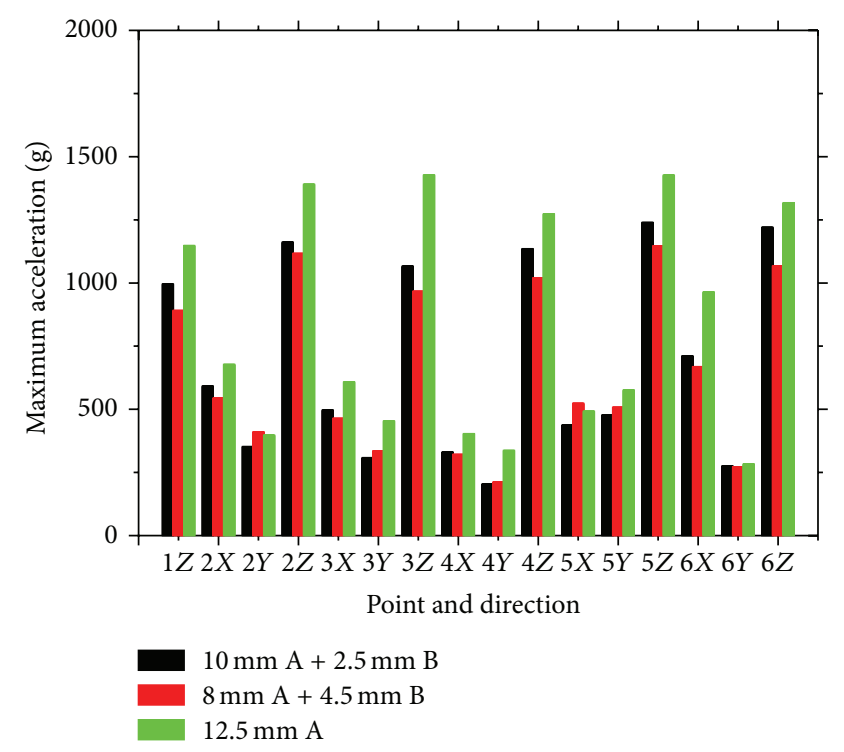

(a) Within spectral domain $8 \mathrm{kHz}$

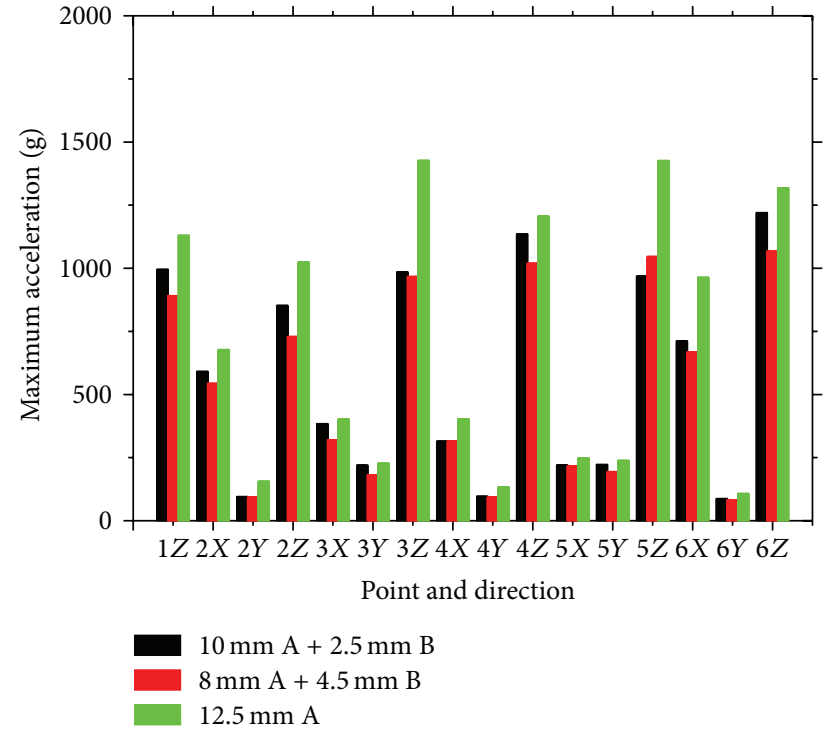

(b) Within spectral domain $4 \mathrm{kHz}$

Figure 5: Contrasts of maximum acceleration at different points and directions.

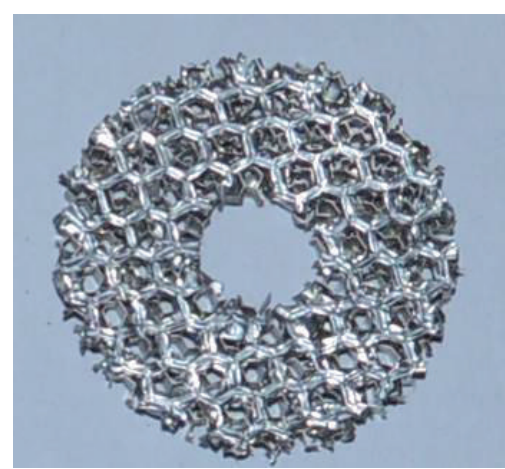

(a) $10 \mathrm{~mm} \mathrm{~A}+2.5 \mathrm{~mm} \mathrm{~B}$

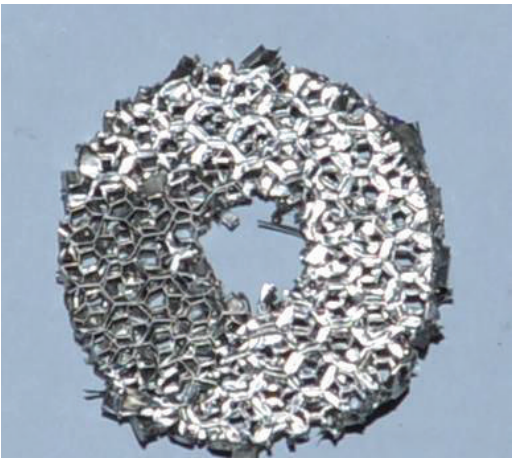

(b) $8 \mathrm{~mm} \mathrm{~A}+4.5 \mathrm{~mm} \mathrm{~B}$

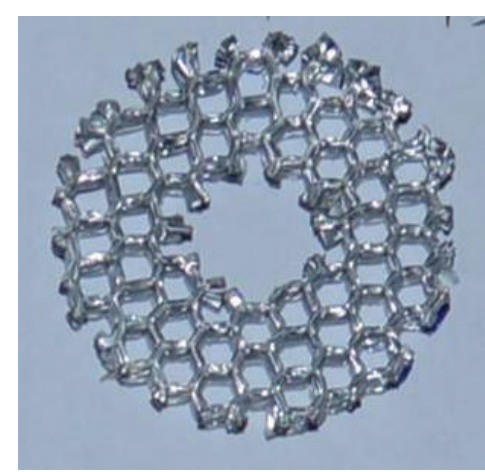

(c) $12.5 \mathrm{~mm} \mathrm{~A}$

FIgURE 6: Samples after impact tests.

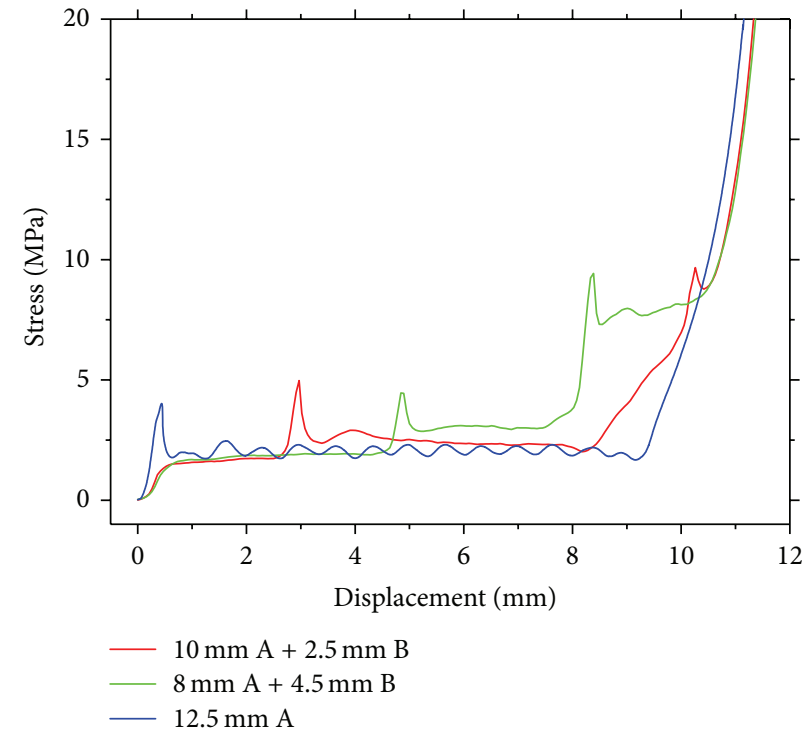

FIgURE 7: Compressive curves of three aluminium honeycomb buffers. 
TABle 3: Experimental results of combined honeycombs $8 \mathrm{~mm} \mathrm{~A}+4.5 \mathrm{~mm} \mathrm{~B}$.

\begin{tabular}{|c|c|c|c|c|c|}
\hline \multirow{2}{*}{$\begin{array}{l}\text { Location and } \\
\text { direction }\end{array}$} & \multirow{2}{*}{$\begin{array}{l}\text { Max. absolute in } \\
\text { time domain (g) }\end{array}$} & \multicolumn{2}{|c|}{ Shock spectral domain (within $8 \mathrm{kHz}$ ) } & \multicolumn{2}{|c|}{ Shock spectral domain (within $4 \mathrm{kHz}$ ) } \\
\hline & & Max. (g) & Corresponding frequency $(\mathrm{Hz})$ & Max. (g) & Corresponding frequency $(\mathrm{Hz})$ \\
\hline$\overline{1 Z}$ & 667 & 891 & 3592 & 891 & 3592 \\
\hline $2 X$ & 210 & 543 & 3805 & 543 & 3805 \\
\hline $2 Y$ & 133 & 410 & 7611 & 93 & 3805 \\
\hline $2 Z$ & 400 & 1117 & 7611 & 729 & 3805 \\
\hline $3 X$ & 182 & 463 & 7184 & 319 & 3805 \\
\hline $3 Y$ & 272 & 335 & 7184 & 182 & 3390 \\
\hline $3 Z$ & 594 & 967 & 3805 & 967 & 3805 \\
\hline $4 X$ & 241 & 321 & 7611 & 315 & 3805 \\
\hline $4 Y$ & 171 & 211 & 7184 & 93 & 3805 \\
\hline $4 Z$ & 508 & 1019 & 3592 & 1019 & 3592 \\
\hline $5 X$ & 225 & 523 & 7611 & 216 & 3390 \\
\hline $5 Y$ & 177 & 508 & 7611 & 194 & 3390 \\
\hline $5 Z$ & 839 & 1146 & 7611 & 1046 & 3805 \\
\hline $6 X$ & 276 & 668 & 3805 & 668 & 3805 \\
\hline $6 Y$ & 124 & 272 & 7611 & 82 & 3805 \\
\hline $6 Z$ & 515 & 1067 & 3592 & 1067 & 3592 \\
\hline
\end{tabular}

TABLE 4: The scatter of maximum acceleration of combined honeycombs $10 \mathrm{~mm} \mathrm{~A}+2.5 \mathrm{~mm}$ B.

\begin{tabular}{lccccc}
\hline Honeycomb & Number & Impact velocity $(\mathrm{m} / \mathrm{s})$ & Max. $(\mathrm{g})$ & Corresponding frequency (Hz) & Location and direction \\
\hline & 1 & 29.3 & 998 & 3805 & $6 Z$ \\
$10 \mathrm{~mm} \mathrm{~A}+2.5 \mathrm{~mm} \mathrm{~B}$ & 2 & 29.3 & 1061 & 7611 & $6 Z$ \\
& 3 & 29.3 & 1239 & 4795 & $5 Z$ \\
\hline Average & 4 & 30.2 & 1330 & 6781 & $6 Z$ \\
\hline
\end{tabular}

TABLE 5: Experimental parameters of honeycomb specimens.

\begin{tabular}{lccc}
\hline Honeycomb & Number & $\begin{array}{c}\text { Impact } \\
\text { velocity }(\mathrm{m} / \mathrm{s})\end{array}$ & $\begin{array}{c}\text { Residual } \\
\text { thickness }(\mathrm{mm})\end{array}$ \\
\hline \multirow{3}{*}{$10 \mathrm{~mm} \mathrm{~A} \mathrm{+} \mathrm{2.5} \mathrm{mm} \mathrm{B}$} & 1 & 29.3 & 2.84 \\
& 3 & 29.3 & 2.57 \\
& 4 & 29.3 & 2.79 \\
\multirow{2}{*}{$8 \mathrm{~mm} \mathrm{~A}+4.5 \mathrm{~mm} \mathrm{~B}$} & 1 & 30.2 & 2.63 \\
\hline \multirow{2}{*}{$12.5 \mathrm{~mm} \mathrm{~A}$} & 2 & 29.1 & 3.81 \\
& 1 & 29.1 & 3.38 \\
\hline
\end{tabular}

Then residual energy $\left(E_{\text {residual }}\right)$ is

$$
E_{\text {residual }}=E_{\text {total }}-E_{\text {absorbed }} \text {. }
$$

The results of absorbed energy are listed in Table 6. From the table, one can see the mean residual energy of combined honeycomb buffer $(8 \mathrm{~mm} \mathrm{~A}+4.5 \mathrm{~mm} \mathrm{~B})$ is the least. The conclusion is consistent with that from the shock response spectrum results. Moreover, when the cushion material is composed of different thickness honeycomb samples, the compression stress of $8 \mathrm{~mm} \mathrm{~A}+4.5 \mathrm{~mm} \mathrm{~B}$ buffer is characterized by step-shaped increase, which maybe is beneficial to lower the shock vibration.

\section{Conclusions}

The shock absorption properties of aluminium honeycomb buffers were tested. In the experiments, two combined aluminium honeycomb buffers $(8 \mathrm{~mm} \mathrm{~A}+4.5 \mathrm{~mm} \mathrm{~B}$ and $10 \mathrm{~mm}$ $\mathrm{A}+2.5 \mathrm{~mm} \mathrm{~B}$ ) and one single aluminium honeycomb buffer were impacted at velocity of around $30 \mathrm{~m} / \mathrm{s}$. An aluminium alloy testing platform with the dimensions of $600 \mathrm{~m} \times$ $600 \mathrm{~mm} \times 20 \mathrm{~mm}$ was used. The aluminium honeycomb buffer was mounted at the centre of the platform, and six groups of acceleration sensors were mounted around the centre. The acceleration response curves of three experiments were obtained. Then the corresponding shock spectrum curves were calculated with the use of fast Fourier transform (FFT). Moreover, the compression properties of three kinds of buffers were tested under quasi-static state, and the energy absorption properties were analysed. The results show that (1) the shock absorption of combined aluminium honeycomb buffer is better than that of single aluminium honeycomb buffer; (2) combined aluminium honeycomb (8 mm A + $4.5 \mathrm{~mm} \mathrm{~B}$ ) buffer is beneficial to smooth the stress and lower the energy applied to the testing platform.

In this work, only a limited number of combined aluminium honeycomb buffers are tested. The more appropriate combination should be found if more experiments are tried. However, the experimental method and results in this paper provide an intuitionistic cognition to the shock absorption of combined aluminium honeycomb structures. Furthermore, 
TABLE 6: Absorbed energy of different honeycomb buffers.

\begin{tabular}{|c|c|c|c|c|c|}
\hline Honeycomb & Number & Total energy $(\mathrm{J})$ & Absorbed energy (J) & Residual energy $(\mathrm{J})$ & Mean residual energy $(\mathrm{J})$ \\
\hline \multirow{4}{*}{$10 \mathrm{~mm} \mathrm{~A}+2.5 \mathrm{~mm} \mathrm{~B}$} & 1 & 19.62 & 4.59 & 15.03 & \multirow{4}{*}{15.18} \\
\hline & 2 & 19.62 & 4.90 & 14.71 & \\
\hline & 3 & 19.62 & 4.65 & 14.97 & \\
\hline & 4 & 20.84 & 4.84 & 16.00 & \\
\hline \multirow{2}{*}{$8 \mathrm{~mm} \mathrm{~A}+4.5 \mathrm{~mm} \mathrm{~B}$} & 1 & 19.35 & 4.52 & 14.83 & \multirow{2}{*}{14.51} \\
\hline & 2 & 19.35 & 5.16 & 14.19 & \\
\hline \multirow{3}{*}{$12.5 \mathrm{~mm} \mathrm{~A}$} & 1 & 18.30 & 3.98 & 14.32 & \multirow{3}{*}{15.49} \\
\hline & 2 & 20.98 & 4.11 & 16.86 & \\
\hline & 3 & 19.48 & 4.18 & 15.30 & \\
\hline
\end{tabular}

some potential applications of the combined aluminum honeycomb such as being designed as buffer in bus, ship, train, and so forth can be expected in the future.

\section{Conflict of Interests}

The authors declare that there is no conflict of interests regarding the publication of this paper.

\section{Acknowledgment}

This work was funded by National Natural Science Foundation of China (Grants no. 11132012 and no. 11172328).

\section{References}

[1] W. Goldsmith and D. L. Louie, "Axial perforation of aluminum honeycombs by projectiles," International Journal of Solids and Structures, vol. 32, no. 8-9, pp. 1017-1046, 1995.

[2] K. B. Shin, J. Y. Lee, and S. H. Cho, "An experimental study of low-velocity impact responses of sandwich panels for Korean low floor bus," Composite Structures, vol. 84, no. 3, pp. 228-240, 2008.

[3] H.-P. Wang, C.-T. Wu, Y. Guo, and M. E. Botkin, "A coupled meshfree/finite element method for automotive crashworthiness simulations," International Journal of Impact Engineering, vol. 36, no. 10-11, pp. 1210-1222, 2009.

[4] M. Li, Z. Deng, R. Liu, and H. Guo, "Crashworthiness design optimisation of metal honeycomb energy absorber used in lunar lander," International Journal of Crashworthiness, vol. 16, no. 4, pp. 411-419, 2011.

[5] V. Crupi, G. Epasto, and E. Guglielmino, "Comparison of aluminium sandwiches for lightweight ship structures: honeycomb vs. foam," Marine Structures, vol. 30, pp. 74-96, 2013.

[6] A. Hönig and W. J. Stronge, "In-plane dynamic crushing of honeycomb. Part I: crush band initiation and wave trapping," International Journal of Mechanical Sciences, vol. 44, no. 8, pp. 1665-1696, 2002.

[7] A. Hönig and W. J. Stronge, "In-plane dynamic crushing of honeycomb. Part II: application to impact," International Journal of Mechanical Sciences, vol. 44, no. 8, pp. 1697-1714, 2002.

[8] D. Ruan, G. Lu, B. Wang, and T. X. Yu, "In-plane dynamic crushing of honeycombs-a finite element study," International Journal of Impact Engineering, vol. 28, no. 2, pp. 161-182, 2003.
[9] D. Mohr and M. Doyoyo, "Nucleation and propagation of plastic collapse bands in aluminum honeycomb," Journal of Applied Physics, vol. 94, no. 4, pp. 2262-2270, 2003.

[10] D. Mohr and M. Doyoyo, "Experimental investigation on the plasticity of hexagonal aluminum honeycomb under multiaxial loading," Transactions ASME-Journal of Applied Mechanics, vol. 71, no. 3, pp. 375-385, 2004.

[11] D. L. McDowell and A.-J. Wang, "Yield surfaces of various periodic metal honeycombs at intermediate relative density," International Journal of Plasticity, vol. 21, no. 2, pp. 285-320, 2005.

[12] W. E. Baker, T. C. Togami, and J. C. Weydert, "Static and dynamic properties of high-density metal honeycombs," International Journal of Impact Engineering, vol. 21, no. 3, pp. 149-163, 1998.

[13] Q. Zhou and R. R. Mayer, "Characterization of aluminum honeycomb material failure in large deformation compression, shear, and tearing," Journal of Engineering Materials and Technology, vol. 124, no. 4, pp. 412-420, 2002.

[14] E. Wu and W. S. Jiang, "Axial crush of metallic honeycombs," International Journal of Impact Engineering, vol. 19, no. 5-6, pp. 439-456, 1997.

[15] H. Zhao and G. Gary, "Crushing behaviour of aluminium honeycombs under impact loading," International Journal of Impact Engineering, vol. 21, no. 10, pp. 827-836, 1998.

[16] V. S. Deshpande and N. A. Fleck, "High strain rate compressive behaviour of aluminum alloy foams," International Journal of Impact Engineering, vol. 24, no. 3, pp. 277-298, 2000.

[17] B. Hou, H. Zhao, S. Pattofatto, J. G. Liu, and Y. L. Li, "Inertia effects on the progressive crushing of aluminium honeycombs under impact loading," International Journal of Solids and Structures, vol. 49, no. 19-20, pp. 2754-2762, 2012.

[18] M. K. Khan, T. Baig, and S. Mirza, "Experimental investigation of in-plane and out-of-plane crushing of aluminum honeycomb," Materials Science and Engineering A, vol. 539, pp. 135142, 2012.

[19] S. Xu, J. H. Beynon, D. Ruan, and G. Lu, "Experimental study of the out-of-plane dynamic compression of hexagonal honeycombs," Composite Structures, vol. 94, no. 8, pp. 23262336, 2012.

[20] A. Alavi Nia and M. Z. Sadeghi, "An experimental investigation on the effect of strain rate on the behaviour of bare and foamfilled aluminium honeycombs," Materials \& Design, vol. 52, pp. 748-756, 2013.

[21] S.-T. Hong, J. Pan, T. Tyan, and P. Prasad, "Quasi-static crush behavior of aluminum honeycomb specimens under 
compression dominant combined loads," International Journal of Plasticity, vol. 22, no. 1, pp. 73-109, 2006.

[22] S.-T. Hong, J. Pan, T. Tyan, and P. Prasad, "Quasi-static crush behavior of aluminum honeycomb specimens under nonproportional compression-dominant combined loads," International Journal of Plasticity, vol. 22, no. 6, pp. 1062-1088, 2006.

[23] S.-T. Hong, J. Pan, T. Tyan, and P. Prasad, "Dynamic crush behaviors of aluminum honeycomb specimens under compression dominant inclined loads," International Journal of Plasticity, vol. 24, no. 1, pp. 89-117, 2008.

[24] M. A. Hazizan and W. J. Cantwell, "The low velocity impact response of an aluminium honeycomb sandwich structure," Composites Part B: Engineering, vol. 34, no. 8, pp. 679-687, 2003.

[25] I. T. Lee, Y. Shi, A. M. Afsar, Y. Ochi, S. I. Bae, and J. I. Song, "Low velocity impact behavior of aluminum honeycomb structures," Advanced Composite Materials, vol. 19, no. 1, pp. 19-39, 2010.

[26] V. Crupi, G. Epasto, and E. Guglielmino, "Collapse modes in aluminium honeycomb sandwich panels under bending and impact loading," International Journal of Impact Engineering, vol. 43, pp. 6-15, 2012.

[27] I. Ivañez and S. Sanchez-Saez, "Numerical modelling of the lowvelocity impact response of composite sandwich beams with honeycomb core," Composite Structures, vol. 106, pp. 716-723, 2013.

[28] C. C. Foo, L. K. Seah, and G. B. Chai, "Low-velocity impact failure of aluminium honeycomb sandwich panels," Composite Structures, vol. 85, no. 1, pp. 20-28, 2008.

[29] M. A. Yahaya, D. Ruan, and M. S. Dargusch, "Response of aluminium honeycomb sandwich panels subjected to foam projectile impact-an experimental study," International Journal of Impact Engineering, vol. 75, pp. 100-109, 2015.

[30] R. Nunes, J. H. Adams, M. Ammons et al., ASM Handbook Volume 2: Properties and Selection: Nonferrous Alloys and SpecialPurpose Materials, ASM Internatioanl, Ohio, Ohio, USA, 1990. 

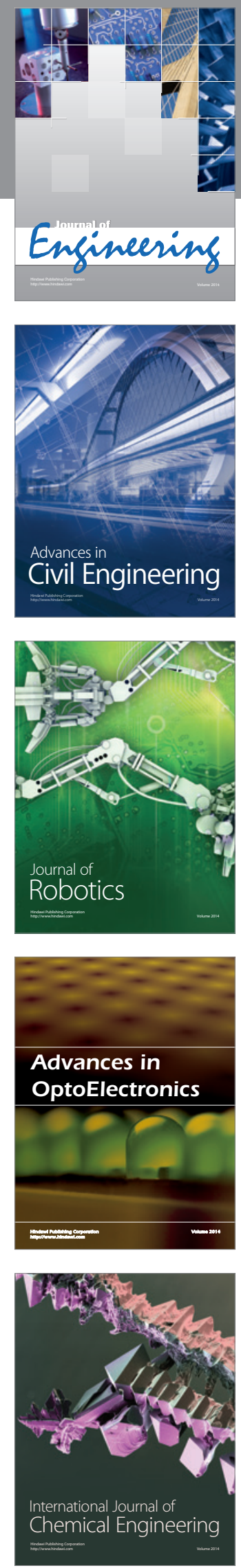

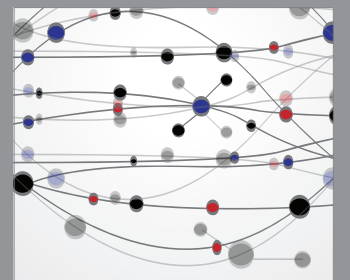

The Scientific World Journal
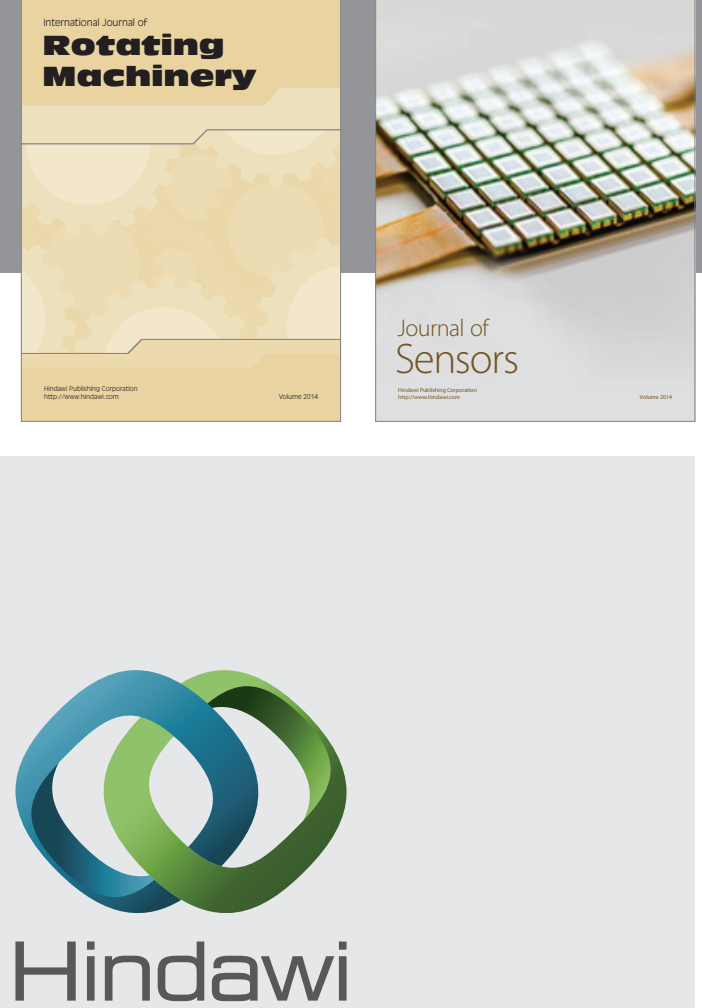

Submit your manuscripts at http://www.hindawi.com
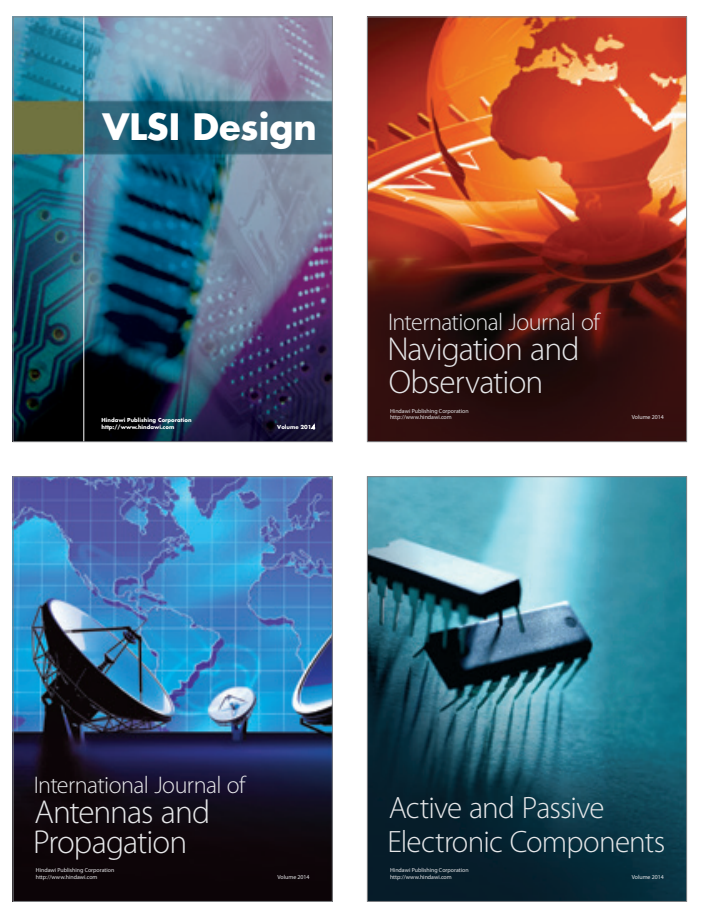
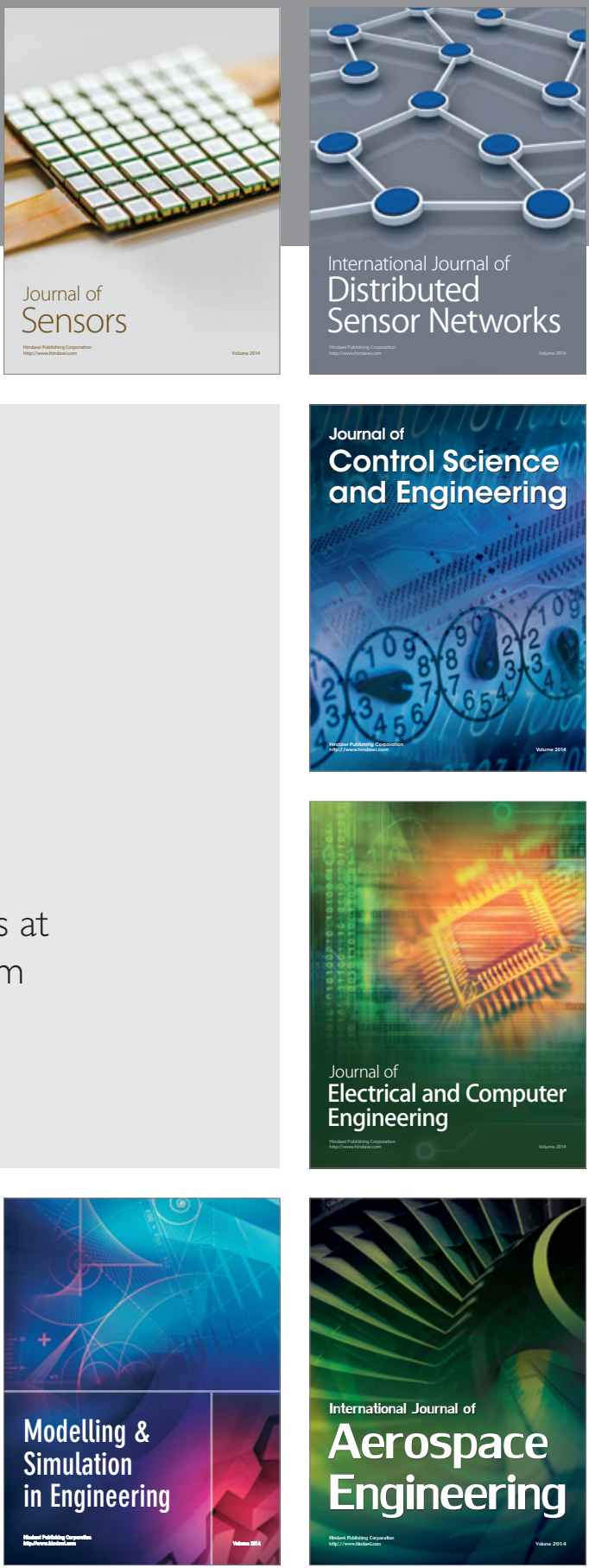

Journal of

Control Science

and Engineering
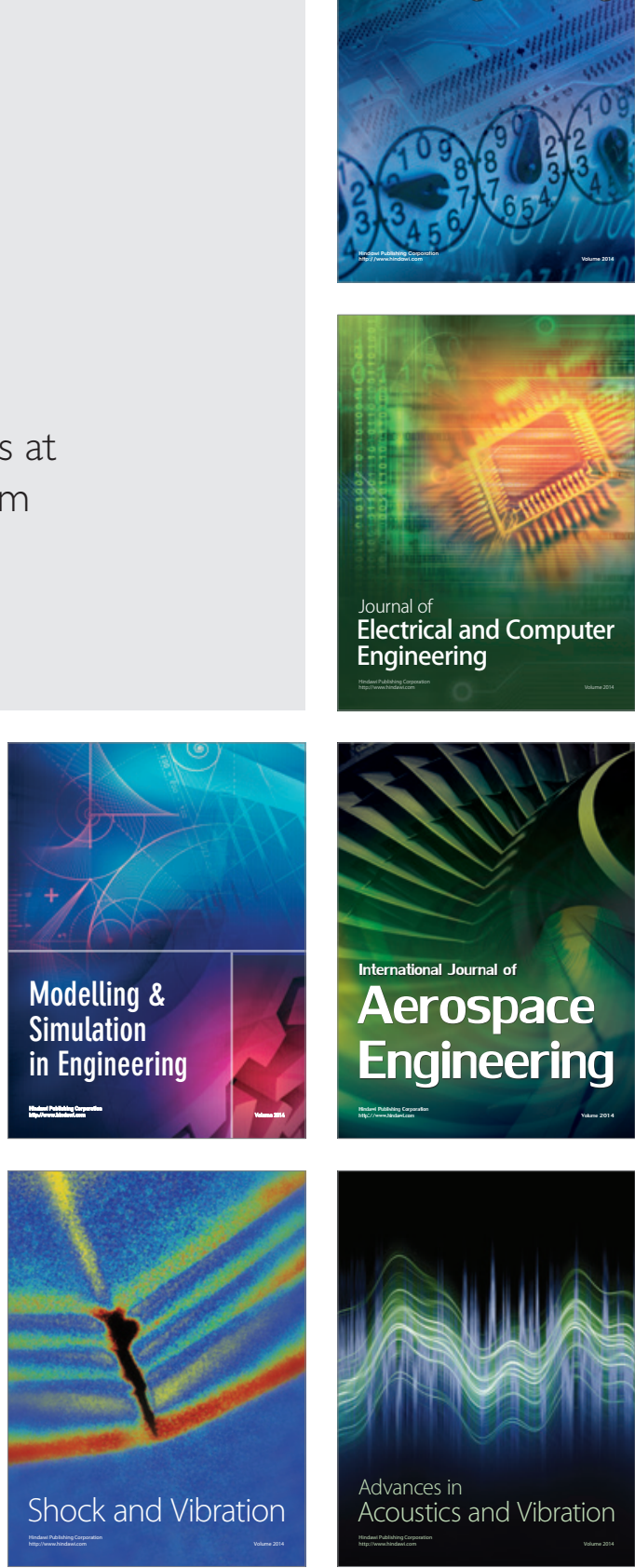